\title{
An integrated approach for fire extinguishers selection with DEMATEL and TODIM methods
}

\section{DEMATEL ve TODIM yöntemleri ile yangın söndürücü seçimi problemine bütünleşik bir yaklaşım}

\author{
Mesut Ulu ${ }^{1}$ \\ Hasan Şahin ${ }^{2}$
}

${ }^{1}$ Lecturer, Bandirma Onyedi Eylul University, Department of Occupational Health and Safety, Balıkesir, Turkey, mulu@bandirma.edu.tr

ORCID: 0000-0002-5591-8674

2 Assist. Prof. Dr, Bursa Technical University, Department of Industrial Engineering, Bursa, Turkey, h.sahin@btu.edu.tr

ORCID: 0000-0002-8915-000X

\section{Corresponding Author:}

Hasan Şahin,

Bursa Technical University, Department of Industrial Engineering, Bursa, Turkey, h.sahin@btu.edu.tr

Submitted: 2/09/2021

Revised: 15/10/2021

Accepted: 25/10/2021

Online Published: 25/12/2021

Citation: Ulu, M., \& Şahin, H., An integrated approach for fire extinguishers selection with DEMATEL and TODIM methods, bmij (2021) 9 (4): 1696-1707, doi: https://doi.org/10.15295/bmij.v9i4.1928

\begin{abstract}
Fire is a type of disaster that has caused significant loss of property and life from past to present. If the necessary measures are not taken, they cause serious property damage, interruption of processes, death and injury. Especially in industrial facilities, the density of flammable, explosive and hazardous chemicals, chimneys, hot surfaces, static electricity and electrical hazards, hot work increases the risk of fire. Therefore, necessary precautions should be taken. The choice of extinguisher device, which includes both passive and active precaution in fire safety, provides the correct intervention in case of possible fire. In case of being a fire, it is necessary to quickly and easily extinguish without damaging the system. For this reason, choosing the right extinguisher is important. In this study, effective criteria were determined by negotiating with supplier companies for the selection of suitable fire extinguishers. After scoring for the criteria, the weights of the criteria were determined by DEMATEL method. With TODIM method, appropriate fire extinguishing agent selection and sequencing were made.
\end{abstract}

Keywords: DEMATEL, Extinguisher Selection, Fire Safety, Multiple-Criteria Decision Analysis, TODIM

Jel Codes: C02, Q59, Q50

Öz

Yangın geçmişten günümüze kadar önemli miktarda mal ve can kayıplarına neden olan bir afet çeşididir. Gerekli önlemler alınmazsa ciddi maddi hasarlara, süreçlerin sekteye uğramasına, ölüm ve yaralanmalara sebep olmaktadır. Özellikle endüstriyel tesislerde parlayıcı, patlayıcı ve tehlikeli kimyasalların yoğunluğu, bacalar, kızgın yüzeyler, statik elektrik ve elektrik kaynaklı tehlikeler, ateşli yapılan işler yangın riskini artırmaktadır. Bu nedenle gerekli önlemler alınmalıdır. Yangın güvenliğinde hem pasif hem de aktif önlem de yer alan söndürücü cihaz seçimi olası yangın durumunda doğru müdahaleyi sağlamaktadır. Yangının olması durumunda sisteme zarar vermeden hızlı ve kolay bir şekilde söndürmek gerekmektedir. Bu sebep ile doğru söndürücü seçimi önem arz etmektedir. Bu çalışmada uygun yangin söndürücü seçimi için tedarikçi firmalar ile görüusülerek etkili olan kriterler belirlenmiștir. Kriterler için puanlama yapıldıktan sonra DEMATEL yöntemi ile kriterlerin ağırlıkları tespit edilmiştir. TODIM yöntemi ile uygun yangın söndürücü madde seçimi ve sıralanması yapılmıştır.

Anahtar Kelimeler: Çok kriterli karar verme, DEMATEL, Söndürücü Seçimi, TODIM, Yangın Güvenliği

JEL Kodları: C02, Q59, Q50 


\section{Introduction}

Increased energy consumption caused by the increasing growth of collective settlements and the development of industrialization carries the risk of fire with it. All the precautions taken to reduce the likelihood of fire causing material damage, injuries and even death are called fire safety. Fire safety precautions aim to allow people to easily move away from the fire area and survive the fire with minimal damage. These precautions can be addressed during the construction of a building or they can be applied to an existing structure afterwards (Demirel, Tavman, \& Yaman, 2017). It is necessary to select an extinguisher suitable for the possible type of fire in the area in order to have an effective response in the first stage of the fire. Thus, it is important to primarily determine the fire classes (Gultek, 2005). There are six types of fire classes (Yangın güvenliği, 2019).

Fire class A: Solid material fires such as wood, paper, fabric etc.

Fire class B: Inflammable and flammable liquid fires such as gasoline, solvent, glue, thinner etc.

Fire class C: Inflammable and flammable gas fires such as methane, butane, LPG etc.

Fire class D: Metal fires such as aluminium, sodium, magnesium etc.

Fire class E: Fire caused by electricity

Fire class F: Fire caused by oils of vegetable or animal origin

Substances such as water, dry chemical powders (ABC powder, BC powder, D powder), halon and its alternatives, $\mathrm{CO} 2$ gas and foam can be used to extinguish these types of fires (Yangın güvenliği, 2019).

Water: This method allows extinguishing through cooling by reducing the heat generated in the fire. It must be used in fires in Class A (Iplikçi, 2006).

Foam: This chemical substance is expanded by air bubbles and it is lighter than water or flammable liquid. It covers the flammable liquid by expanding when in contact with air, cutting off the fire's contact with air. It comes in various types such as low, medium, high expansion, protein, synthetic-based and film forming (Kilic, 2003). Foam is primarily used in responding to Class B liquid fires. It can also be used in fire class A. Foam should not be applied to flammable chemicals that react with water.

Dry chemical extinguishers: These are borax, sodium bicarbonate, monoammonium phosphate, potassium bicarbonate, potassium chloride-based non-toxic powder mixtures that are effective in fire extinguishing when applied as a powder. Dry chemical extinguisher powders are effective in extinguishing fire classes A, B and C. Dry chemical powder extinguishing systems cover the area to which they are applied, and enter a fire-stopping chemical reaction with the flammable materials that are either burning or preparing to burn while suspending in the air and cut off contact with oxygen. They extinguish the fire by preventing combustion and reignition. Thus, they can stop and suffocate the chain reaction based on the chemical effect (Iplikçi, 2006).

Carbon dioxide (CO2): It is effective in fire classes B and C. Since CO2 is not a toxic gas and can only suffocate when it reaches a very high density in the environment, $\mathrm{CO} 2$ extinguishers are one of the most commonly used fire extinguishers in electrical fires for their insulating properties. As they leave no waste/residue after use, these fire extinguishers are preferred in places such as kitchens, laboratories, etc. It should also be known that they are not effective in fire class A (Kilic, 2003).

Halon alternative extinguishers (Halocarbon): The halon alternative halogen hydrocarbons used as fire extinguishers are gases that contain one or more of fluorine, chlorine or bromine elements, do not have electrical conductivity where one or more organic compounds are used as the main component, and extinguish the fire by filling the volume in the fire area in closed spaces.

There are several studies in the literature on fire safety, fire safety precautions and fire extinguishing system selection. Gultek (2005) proposed a method to be used at the design stage of atrium shopping malls to meet the fire safety requirements. Gultek scrutinized country legislation (TS and BYKHY), American (NFPA) and European (BS and BR) legislation within the framework of escape routes and building evacuation times and conducted comparative analyses (Gultek, 2005). In a study on the general framework of fire safety precautions, Iplikci (2006) set out the decisions to be taken on fire safety at the planning stage. Kilic (2003) introduced fire safety precautions in buildings and fire extinguishing systems used to extinguish fires, determining the selection principles of fire extinguishing systems based on the type and conditions of fire in possible fire risks. Many R\&D and innovation project selection models and techniques have emerged in the literature, including qualitative and quantitative approaches. These selection models can be classified as mathematical models (linear programming or 
goal programming), financial models (net present value or cost-benefit analysis), and decision theory models (multi-criteria decision making or decision trees) (Kurt \&Yildiz, 2020). Decision making and decision analysis, one of the most important components of management science, is a field of study as old as humanity (Yildiz \& Demir, 2019).

Multi-objective decision-making methods are analytical methods (Yildiz \& Yayla, 2015). In this study, passive house active precautions were taken in terms of fire safety, and the fire extinguisher device suitable for the appropriate workplace was selected by using the multi-criteria decision-making methods DEMATEL and TODIM. There are very few studies on fire extinguisher selection.

The DEMATEL method used in the study was developed to improve the understanding of specific problems, to contribute to the identification of hierarchically applicable solutions, and to pioneer the use of appropriate scientific research methods for interlocking problem clusters. The graph theorybased DEMATEL, which divides factors into cause-and-effect groups to draft the problems and better understand the causal relationship, provides the opportunity to solve problems (Li \& Tzeng, 2009). Another method used in the study, TODIM, uses the function of prospect theory and gives us a ranking of alternatives by calculating the dominance of one alternative over another (Sen, Datta, \& Mahapatra, 2015). As the authors of one of the few studies that use the DEMATEL-TODIM methods together in the literature, Mahmoodi and Jahromi (2014) tried to prevent uncertainty by using the indefinite number as data with the hybrid fuzzy DEMATEL-TODIM approach, they proposed to sort and find the criteria. Unal \& Cetin (2020) discussed the CRM software selection of a five-star accommodation business in Antalya. They used the Delphi method together with DEMATEL and TODIM methods.

In this study, the TODIM method, which is frequently used in the literature, was used together with the DEMATEL method, which determines the relationship between the criteria, to solve the problem of extinguisher selection. In the study, the inter-criteria relationship obtained by the DEMATEL method was associated with the weight values of criteria to find the dependent criterion weight values, and then the selection and ranking were made in a decision matrix with the TODIM method.

\section{Solution methods}

In our study, we first determined the inter-criteria relationship and criteria weight with the DEMATEL method and then used the TODIM and DEMATEL methods together to solve the extinguisher selection problem.

\section{DEMATEL method}

The Decision-Making Trial and Evaluation Laboratory (DEMATEL) Method; the DEMATEL method was developed by the Geneva Research Centre of the Battelle Memorial Institute between 1972 and 1976 to solve complex and intertwined problem groups in research (Aksakal \& Dağdeviren, 2010).

The method was used to study the inter-criteria interactions in multi-criteria decision-making problems and to determine the central problems in terms of their different factors, dimensions and aspects. As a graph theory-based approach, the method reveals the causal relationships between complex problems by dividing their components into cause-and-effect groups. The method also gives the opportunity to take into account not only direct effects but indirect effects as well (Cinar, 2013).

The most important advantage of the DEMATEL method is that it includes indirect relationships with a compromised cause-effect model. This method, which is effective in determining the criterion weights, is used with many other criterion decisions making methods to rank the alternatives. At the same time, DEMATEL is an effective method that examines the structure and relations between system components or a valid number of alternatives, and it is a method that can arrange the criteria in order of priority in terms of the type of relations and the importance of their effects on each other. Criteria that have more influence over other criteria and are assumed to be of high priority are called cause criteria. In contrast, criteria that are more affected and are considered to have low priority are called outcome criteria. DEMATEL is a successful method for determining criterion weights, but it should be used in conjunction with another multi-criteria decision-making method to rank alternatives.

DEMATEL is one of the objective criteria weight calculation methods that is frequently used in the literature. Below are some of the studies using this method:

Liou, Yen, \& Tzeng (2008), fuzzy logic and DEMATEL methods were combined to create an effective safety management system for airlines including organizational and management factors. Li \& Tzeng, (2009), a threshold value was determined using the maximum mean de-entropy algorithm to find the critical services provided by the semiconductor intellectual property centre with the DEMATEL method (Li \& Tzeng, 2009). Aksakal \& Dagdeviren (2010), the personnel selection process for an international 
company was addressed and the selection was made by developing an algorithm integrated with the DEMATEL method and the Analytical Network Process (AAS) for the solution of the problem. ChiaHsu, Kuo, Chen, \& Hu, (2013), the DEMATEL method was used to develop a carbon management model for supplier selection in green supply chain management. Cinar (2013), with an integrated approach using probabilistic DEMATEL and simple weighting methods, the multi-criteria decision problem faced by individuals in a sample of university students and graduates in determining their career or field of work was structurally modeled, and the results were associated with individuals' attitudes towards risk. Birgün \& Ulu (2020) used the DEMATEL method to select a site for an Industry 4.0-focused training center. Efe \& Efe (2019) investigated the relationship between the risk factors that cause work accidents with the DEMATEL method.

The DEMATEL method follows the following steps respectively to determine the relationship between criteria and weights (Efe \& Efe, 2016):

Step 1: The relationships between criteria are determined by an expert group using the paired comparison scale in Table 1. Scoring can be made within the range of 0-3 or 0-4. The numerical values show the extent to which one criterion affects the other (Cinar, 2013).

Table 1: A Comparison scale of the DEMATEL method

\begin{tabular}{|c|c|}
\hline Numeric Value & Definition \\
\hline 0 & No influence \\
\hline 1 & Very low influence \\
\hline 2 & Low influence \\
\hline 3 & High influence \\
\hline 4 & Very high influence \\
\hline
\end{tabular}

Step 2: If there are two or more experts evaluating the criteria, the arithmetic average of the given scores is taken. Then these values are placed in the matrix. An asymmetric matrix with "0" diagonals is obtained. This matrix is called the direct relation matrix $(X)$.

$$
\mathbf{X}=\left|\begin{array}{ccc}
0 & \ldots & X_{1 n} \\
\vdots & \ddots & \vdots \\
X_{n 1} & \ldots & 0
\end{array}\right|
$$

Step 3: With the direct relation matrix, the highest among each row and column sum is found as shown in Equation 1.

$$
s=\max \left(\max \sum_{j=1}^{n} X i j, \sum_{i=1}^{n} X i j\right)
$$

Then, the normalized direct relation matrix (C) is obtained in Equation 2 by dividing each element of the matrix by the "s" value.

$$
C=\frac{X}{S}
$$

Step 4: As seen in Equation 3, the C matrix is subtracted from the unit matrix, inverted and multiplied again by the $\mathrm{C}$ matrix.

$$
\begin{gathered}
\lim _{H \rightarrow \infty} C+C^{2}+C^{3}+\cdots+C^{H} \\
F=C+C^{2}+C^{3}+\cdots+C^{H}=C(I-C)^{-1}
\end{gathered}
$$

This operation gives the total relation matrix $(\mathrm{F})$.

Step 5: To determine the affecting and affected factor groups and to calculate the net effect degrees in this step, the row and column sums are found after the total relation matrix $(\mathrm{F})$ is determined (Cinar, 2013). For each criterion, these values specify as follows: 
The sum of each row (Di) specifies how one criterion directly or indirectly affects the other criteria,

In addition, the sum of each column (Ri) specifies the sum of direct or indirect effects of the criterion from other criteria.

$\mathrm{Di}+\mathrm{Ri}$ specifies the total effect value sent and received for each criterion,

Di-Ri specifies the total effect of the criterion on the system for each criterion.

$\mathrm{Di}+\mathrm{Ri}$ indicates the importance of the criterion in the system.

If the Di-Ri value is positive, it is the affecting one, and if it is negative, it is the affected one.

Step 6: In this step, an effect-oriented scatter graph is drawn after the threshold value of the matrix is determined. Criteria above the threshold value are determined to be the affecting ones and their effect direction is indicated by an arrow in the diagram. The diagram also shows if a criterion affects itself. The arrows go from the affecting to the affected. The threshold value can be determined by experts. If it is not possible, it can also be determined by averaging the total relation matrix (F).

Step 7: In order to get the criteria weight, $\mathrm{Di}+\mathrm{Ri}$ square and the sum of Di-Ri square are extracted.

$$
W_{i j}=\sqrt{\left(D_{i}-R_{i}\right)^{2}+\left(D_{i}+R_{i}\right)^{2}}
$$

Then, each weight is divided by the sum of the weights, and the criterion weights are found.

$$
W_{i}=\frac{W_{i a}}{\sum_{i=1}^{n} W_{i a}}
$$

\section{TODIM method}

The Portuguese acronym of the "Interactive and Multi-criteria Decision-Making" method, TODIM was introduced in its current form in the early 1990s. The method is based on the "Prospect Theory", which was put forward by Kahneman and Tversky in the 1970s and received the Nobel Prize. While other multi-criteria decision-making methods focus on a solution that always corresponds to the highest value, the TODIM method uses a measurement value that can be calculated through the application of the "Prospect Theory" paradigm (Gomes, 2009). The TODIM method requires numerical values for the criteria to evaluate the alternatives. A verbal scale can also be used for qualitative criteria, and then it is converted into a quantitative scale. The numerical evaluation for alternatives to all criteria constitutes the evaluation matrix. With this matrix, the normalized matrix is obtained by dividing the alternative value of each criterion by the total value of the alternatives. This way, a matrix is obtained with all the components between zero-one and each column sum equal to one. $\mathrm{N}$ in a normalized Pnm matrix refers to the number of alternatives while M refers to the number of criteria (Gomes, 2009; Unal \& Cetin, 2020).

The main purpose of the TODIM method is to measure the dominance degree of each alternative relative to the remainder with the help of the residual value function. In order to achieve this purpose, a value function is used in the method and the shape of this function is the same as the gain and loss function in the expectation theory. With this function, the concepts of gain and loss can be expressed simultaneously. In addition, this function can reflect the behavioural characteristics of the decisionmaker, such as the choice of reference criterion or risk aversion, and this can be counted as the advantage of the method. Instead of the criterion with the highest weight, another criterion can be selected as the reference criterion, changes in the value of the loss aversion coefficient can be made to observe the differences in the results.

The TODIM method has become quite popular in recent years among the multi-criteria decision-making methods. In the literature, there are many more studies in which the TODIM method is used in different areas. It has been used in prioritizing information systems (Costa, Almeida \& Gomes, 2002), assessing inhabitable property (Gomes, 2009), determining the best destination alternatives for natural gas reserves (Gomes, Rangel, \& Maranhão, 2009), selecting settlements (Tosun \& Akyüz, 2015), and the course selection of students (Adali, Işik, \& Kundakci, 2016). In addition, Tseng, Lin, Lim, \& Teehankee (2015) used the fuzzy set theory, the TODIM method and the nonadditive Choquet integral in evaluating the service innovations in the hotel management industry. Mahmoodi \& Jahromi (2014) used the DEMATEL and TODIM methods together to determine the criteria weight of information management in a supply chain network. Sen, Datta, \& Mahapatra, (2015) applied the TODIM method based on gray numbers to the robot selection problem. Sen et al. (2015) contributed to a mathematical basis of TODIM together with the gray numbers set theory for logical decision-making. Adali, Işik, \& 
Kundakci (2016) used the TODIM method in selecting elective courses. Zhang \& Xu (2014), used the TODIM method, based on the probability theory in a way that can effectively capture the psychological behavior of a decision maker, to solve a decision-making problem on evaluating and ranking the service quality among domestic airlines. Tseng et al. (2015) used a quantitative approach, which is the TODIM method, to analyse the criteria and aspects of service innovation in the thermal hotel industry and whether such aspects and criteria apply a weighting ranking for service providers in customer perceptions and real data. Tosun \& Akyüz (2015) used the fuzzy TODIM approach for the supplier selection problem. Wei, Ren, \& Rodríguez (2015) used the classical TODIM method to solve the multicriteria decision-making problems that deal with unstable fuzzy linguistic term sets and take into account the psychological behaviour of the decision maker. Costa, Almeida, \& Gomes (2002) determined how to select the modules of an information system by using the interactive multi-criteria decision-making TODIM method as a multi-criteria decision approach. Gomes \& Rangel (2009), defined reference values for rents of properties using the TODIM Multi-Criteria Decision Assistance method in a study they conducted with real estate agents in Volta Redonda, Brazil. Gomes, Rangel, \& Maranhão, (2009) used the TODIM method to solve the problem of selecting the best destination for the recently discovered natural gas reserves in the Mexilhão field in the Santos basin of Brazil.

The steps for applying the TODIM method can be summarized as follows:

Step 1: The criteria in a problem are divided into two according to their qualitative and quantitative data. The qualitative criteria set $(\mathrm{O})$ and quantitative criteria set $(\mathrm{C})$ are determined. Then an initial matrix is created with a decision matrix $(\mathrm{X})$ containing all the data in the problem.

$$
X=\left[X_{i j}\right] m * n=\left|\begin{array}{ccc}
X_{11} & \ldots & X_{1 n} \\
\vdots & \ddots & \vdots \\
X_{m 1} & \ldots & X_{m n}
\end{array}\right|,(\mathrm{i}=1,2 \ldots, \mathrm{m} \text { ve } \mathrm{j}=1,2 \ldots, \mathrm{n})
$$

Step 2: The decision matrix is normalized by linear normalization. Normalization operations are performed separately, as seen in Equation (7) and Equation (8), respectively, for the benefit and cost criteria:

$$
\begin{aligned}
& r_{i j}=\frac{x_{i j}-\min \left(X_{i j}\right)}{\max \left(X_{i j}\right)-\min \left(X_{i j}\right)},(i=1,2, \ldots, m v e j=1,2, \ldots, n) \\
& r_{i j}=\frac{\max \left(X_{i j}\right)-x_{i j}}{\max \left(X_{i j}\right)-\min \left(X_{i j}\right)},(i=1,2, \ldots, m v e j=1,2, \ldots, n)
\end{aligned}
$$

Step 3: Then the decision-maker decides on the reference criterion by calculating the weight (wj) of each criterion. The reference criterion is the most significant criterion for the decision-maker. The relative weight (wjr) of j. criterion to the reference criterion $(\mathrm{Cr})$ is calculated with Equation (9):

$$
w_{j r}=w_{j} / w_{r}
$$

wr in this formula refers to the weight of the reference criterion. The criterion with the highest weight is used as the reference criterion in this study.

Step 4: The dominance score $\delta(A i, A j)$ of Ai alternative to the $A j$ is calculated by Equation (10):

$$
\delta\left(\mathrm{A}_{i}, \mathrm{~A}_{j}\right)=\sum_{j=1}^{n} \varphi_{c}\left(\mathrm{~A}_{i}, \mathrm{~A}_{j}\right) \quad \forall(\mathrm{i}, \mathrm{j})
$$

In Equation (5), the partial dominance score of Ai alternative under j. criterion to the Aii alternative $\varphi j$ $(\mathrm{Ai}, \mathrm{Aj})$; in other words, the contribution of $\mathrm{j}$. criterion to the dominance score of Ai alternative to the $\mathrm{Aj}$ alternative is calculated by Equation (11):

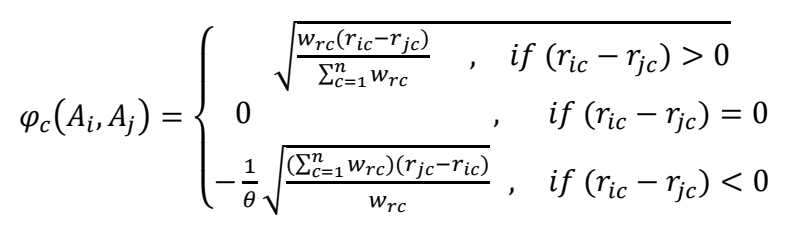


$r_{i c}-r_{j c}>0$ and $r_{i c}-r_{j c}<0$ show the gain or loss of $\mathrm{A}_{\mathrm{i}}$ alternative against $\mathrm{Aj}$ alternative under $\mathrm{j}$. criterion. $\theta$ indicates the loss aversion coefficient. In case of loss aversion, $\theta>1$. As the $\theta$ changes, the shape of the expected value function changes in the negative region of the coordinate system (Adali, Işik, \& Kundakci, 2016).

Step 5: And a ranking of alternatives is obtained in this last step. For this, the overall dominance score ( $\xi i)$ of the alternative Ai is obtained with Equation (12) by normalizing the dominance scores calculated in the previous scores:

$$
\xi_{i}=\frac{\sum_{j=1}^{m} \delta\left(\mathrm{A}_{i}, \mathrm{~A}_{j}\right)-\min \sum_{j=1}^{m} \delta\left(\mathrm{A}_{i}, \mathrm{~A}_{j}\right)}{\max \sum_{j=1}^{m} \delta\left(\mathrm{A}_{i}, \mathrm{~A}_{j}\right)-\min \sum_{j=1}^{m} \delta\left(\mathrm{A}_{i}, \mathrm{~A}_{j}\right)}
$$

Moreover, the alternatives are ranked by sorting the overall dominance scores calculated for each alternative in descending order. This means that the higher the overall dominance score of an alternative, the higher it gets in the ranking.

\section{The research findings and discussion}

This study focuses on the selection of extinguishers in a glue factory in Istanbul with a closed area of 18.000 square meters. The glue factory has a range of over 100 products such as solvent-based, waterbased, holment adhesives and polyurethane holment adhesives. Possible fires in the factory can be considered as solid, liquid, electrical and chemical. More precautions should be taken against liquid fires, especially when the substances produced in the factory are in a liquid paste-like state. Thus, 4 (A1, $\mathrm{A} 2, \mathrm{~A} 3, \mathrm{~A} 4)$ alternatives and $5(\mathrm{C} 1, \mathrm{C} 2, \mathrm{C} 3, \mathrm{C} 4, \mathrm{C} 5)$ criteria were taken into account in the study for the selection of extinguishers in liquid fires. The criteria and their brief descriptions used in the evaluation are given in Table 2.

Table 2: Criteria Used in the Study and Their Brief Explanations

\begin{tabular}{|l|l|}
\hline Criterion Name & Explanation \\
\hline Accordance (C1) & $\begin{array}{l}\text { The most suitable and effective extinguisher, especially according to the type of } \\
\text { flammable material }\end{array}$ \\
\hline Not harmful (C2) & $\begin{array}{l}\text { Substances that are not harmful for the environment and can be reused after } \\
\text { extinguishing }\end{array}$ \\
\hline Filling and maintenance (C3) & Cost of filling and maintenance to be done at certain intervals \\
\hline Efficiency (C4) & Extinguishing performance on flammable material \\
\hline Cost (C5) & The initial price to be taken for the extinguisher \\
\hline
\end{tabular}

The criteria were evaluated by the experts working in the glue factory using the paired comparison scale in Table 1. The "Direct Relation Matrix (X)" was obtained after expert evaluations. The arithmetic mean of evaluators' scores was taken in creating the direct relation matrix.

Table 3: Direct Relation Matrix $(X)$

\begin{tabular}{|l|l|l|l|l|l|}
\hline Criterias & C1 & C2 & C3 & C4 & C5 \\
\hline C1 & 0 & 3 & 3 & 2 & 3 \\
\hline C2 & 1 & 0 & 2 & 1 & 3 \\
\hline C3 & 2 & 3 & 0 & 1 & 3 \\
\hline C4 & 2 & 4 & 3 & 0 & 4 \\
\hline C5 & 2 & 3 & 2 & 1 & 0 \\
\hline
\end{tabular}

The 13 value, which is the highest of the row and column sums of the direct relation matrix, was taken as the "s value". Then, each element of the matrix was divided by this value, resulting in the "Normalized Direct Relation Matrix (C)" seen in Table 4.

Table 4: Normalized Direct Relationship Matrix (C)

\begin{tabular}{|l|l|l|l|l|l|}
\hline Criterias & C1 & C2 & C3 & C4 & C5 \\
\hline C1 & 0,000 & 0,231 & 0,231 & 0,154 & 0,231 \\
\hline C2 & 0,077 & 0,000 & 0,154 & 0,077 & 0,231 \\
\hline C3 & 0,154 & 0,231 & 0,000 & 0,077 & 0,231 \\
\hline C4 & 0,154 & 0,308 & 0,231 & 0,000 & 0,308 \\
\hline C5 & 0,154 & 0,231 & 0,154 & 0,077 & 0,000 \\
\hline
\end{tabular}


After the Normalized Direct Relation Matrix is created, the Total Relation Matrix (F) shown in Table 5 is obtained by performing the operation in Equation 2.

Table 5: Total Relationship Matrix (F)

\begin{tabular}{|l|l|l|l|l|l|}
\hline Criterias & C1 & C2 & C3 & C4 & C5 \\
\hline C1 & 0,316 & 0,721 & 0,609 & 0,360 & 0,721 \\
\hline C2 & 0,283 & 0,352 & 0,407 & 0,220 & 0,539 \\
\hline C3 & 0,390 & 0,623 & 0,342 & 0,259 & 0,623 \\
\hline C4 & 0,492 & 0,850 & 0,665 & 0,258 & 0,850 \\
\hline C5 & 0,366 & 0,584 & 0,445 & 0,243 & 0,397 \\
\hline
\end{tabular}

After obtaining the Total Relation Matrix, D, R, D+R, and D-R were found and shown in Table 6. In addition, 0.477, which is the average of the Total Relation Matrix, was determined as the threshold value. Figure 1 shows the effect-oriented graphic diagram drawn with the $(D+R)$ and $(D-R)$ values of the criteria.

Table 6: Affecting and Affected Factor Groups

\begin{tabular}{|l|l|l|l|}
\hline $\mathrm{D}$ & $\mathrm{R}$ & $\mathrm{D}+\mathrm{R}$ & $\mathrm{D}-\mathrm{R}$ \\
\hline 2,727 & 5,138 & 4,574 & 0,880 \\
\hline 1,802 & 3,320 & 4,932 & $-1,329$ \\
\hline 2,237 & 4,083 & 4,705 & $-0,231$ \\
\hline 3,116 & 5,740 & 4,456 & 1,776 \\
\hline 2,034 & 3,703 & 5,165 & $-1,096$ \\
\hline
\end{tabular}

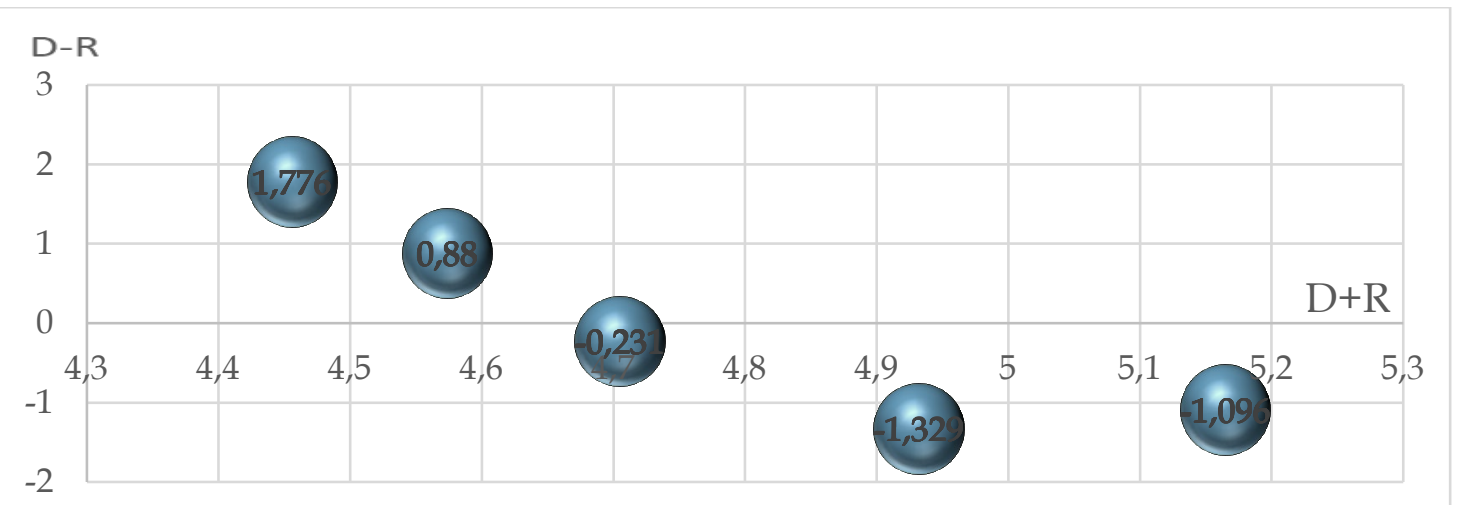

Figure 1: Influential Graph Diagram

Criterion weights were found in the last step of the DEMATEL method, and the criteria were sorted according to their degree of priority. As can be seen in Table 7, cost turned out to be the most important criterion in the system. In addition, the most insignificant criterion was the suitability criterion with a weight of $19 \%$. Then, the criterion weights obtained were used in the selection of alternatives with the TODIM method.

Table 7: Criterion Weights and Criteria Priorities Table

\begin{tabular}{|l|c|c|c|}
\hline Criteria & $\sqrt{(D+R)^{2}+(D-R)^{2}}$ & Criterion weights $(\mathrm{W})$ & Priority criterion \\
\hline C1 & 4,658 & 0,190 & 5 \\
\hline C2 & 5,108 & 0,208 & 2 \\
\hline C3 & 4,710 & 0,192 & 4 \\
\hline C4 & 4,797 & 0,195 & 3 \\
\hline C5 & 5,280 & 0,215 & 1 \\
\hline Total & 24,553 & 1,000 & \\
\hline
\end{tabular}

After the criterion weights and inter-criteria relationship were determined with the DEMATEL method, a Decision Matrix (A) was created with the criteria and alternatives to apply the steps of the TODIM method, which can be seen in Table 8. Three of these criteria (C1, C2 and C4) contain qualitative data and a 5-scale was used to evaluate the extinguishers based on these criteria (1: Very Bad, 2: Bad, 3: Average, 4: Good, 5: Very Good). Moreover, two criteria (C3 and C5) contain quantitative data (cost). 
Table 8: Decision Matrix (A)

\begin{tabular}{|l|l|l|l|l|l|}
\hline Extinguisher type & C1 & C2 & C3 & C4 & C5 \\
\hline Foam Extinguisher (A1) & 4 & 3 & 25 & 5 & 110 \\
\hline Dry Chemical Powder (A2) & 5 & 2 & 30 & 4 & 130 \\
\hline Carbon Dioxide Gas (A3) & 4 & 5 & 60 & 5 & 250 \\
\hline Halocarbon Gas (A4) & 3 & 2 & 80 & 3 & 300 \\
\hline
\end{tabular}

After criterion weights were determined, the decision matrix seen in Table 8 was normalized with Equation (7) and Equation (8) to be used in TODIM methods. The normalized decision matrix can be found in Table 9.

Table 9: Normalized Decision Matrix

\begin{tabular}{|l|l|l|l|l|l|}
\hline & C1 & C2 & C3 & C4 & C5 \\
\hline A1 & 0,500 & 0,333 & 1,000 & 1,000 & 1,000 \\
\hline A2 & 1,000 & 0,000 & 0,909 & 0,500 & 0,895 \\
\hline A3 & 0,500 & 1,000 & 0,364 & 1,000 & 0,263 \\
\hline A4 & 0,000 & 0,000 & 0,000 & 0,000 & 0,000 \\
\hline
\end{tabular}

The TODIM method uses the normalized decision matrix in Table 9 and the criterion weights in Table 7 as data. The criterion with the highest weight has been accepted as the reference criterion in this study. The relative weights (wjr) of each criterion to the reference criterion were calculated with Equation (9) and given in Table 10.

Table 10: Relative Criteria Weights

\begin{tabular}{|l|l|l|l|l|l|l|}
\hline & $\mathrm{C} 1$ & $\mathrm{C} 2$ & $\mathrm{C} 3$ & $\mathrm{C} 4$ & $\mathrm{C} 5$ & Total \\
\hline $\mathrm{W}_{\mathrm{j}}$ & 0,190 & 0,208 & 0,192 & 0,195 & 0,215 & 1,00 \\
\hline $\mathrm{W}_{\mathrm{jr}}$ & 0,884 & 0,967 & 0,893 & 0,907 & 1,000 & 4,65 \\
\hline
\end{tabular}

The dominance score of each alternative to the other alternative based on criteria $\varphi(\mathrm{Ai}, \mathrm{Ai})$ was calculated with Equation (11). Here, the value $\theta$ was taken as 1 . Taking all the criteria into account, the dominance score of $\mathrm{Ai}$ alternative to the $\mathrm{Aj}$ alternative was calculated with Equation (10). $\delta\left(A \_i, A \_j\right)$ Only the dominance scores of the A1 alternative to the other alternatives were shown in Table 11 as an example. The same calculations were repeated for other alternatives and the overall dominance scores for each alternative were found with Equation (12).

Table 11: A1 Alternative's Dominance Scores for Other Alternatives

\begin{tabular}{|l|l|l|l|l|l|l|}
\hline & $\varphi_{1}\left(\mathrm{~A}_{\mathrm{i}}, \mathrm{A}_{\mathrm{j}}\right)$ & $\varphi_{2}\left(\mathrm{~A}_{\mathrm{i}}, \mathrm{A}_{\mathrm{j}}\right)$ & $\varphi_{3}\left(\mathrm{~A}_{\mathrm{i}}, \mathrm{A}_{\mathrm{j}}\right)$ & $\varphi_{4}\left(\mathrm{~A}_{\mathrm{i}}, \mathrm{A}_{\mathrm{j}}\right)$ & $\varphi_{5}\left(\mathrm{~A}_{\mathrm{i}}, \mathrm{A}_{\mathrm{j}}\right)$ & Total \\
\hline A1, A2 & $-1,622$ & 0,263 & 0,132 & 0,312 & 0,150 & $-0,764$ \\
\hline A1, A3 & 0,000 & $-1,790$ & 0,350 & 0,000 & 0,398 & $-1,043$ \\
\hline A1, A4 & 0,308 & 0,263 & 0,438 & 0,442 & 0,464 & 1,915 \\
\hline \multicolumn{7}{|r|}{} \\
\hline
\end{tabular}

Table 12: Overall Dominance Scores for Each Alternative

\begin{tabular}{|l|l|l|}
\hline Alternatives & $\delta\left(A_{i}, A_{j}\right)$ & Sorting \\
\hline A1 & 0,1 & 1,000 \\
\hline A2 & $-5,136$ & 0,791 \\
\hline A3 & $-5,845$ & 0,763 \\
\hline A4 & $-24,983$ & 0,000 \\
\hline
\end{tabular}

The extinguishers were ranked as $\mathrm{A} 1>\mathrm{A} 2>\mathrm{A} 3>\mathrm{A} 4$ according to the overall dominance scores given in Table 12. Accordingly, we found that the A1 extinguisher device was the best fire extinguisher and the worst device was the 4 th alternative, namely A4.

\section{Conclusion and recommendations}

In this study, DEMATEL and TODIM, which are multi-criteria decision-making methods, were applied to the problem of selecting the best fire extinguisher for a glue factory. First, criteria were determined 
to ensure active fire safety and to ensure accurate and quick response in case of fire in a glue factory. Criterion weights were calculated with the DEMATEL method instead of the frequently used AHP method, and the purchasing cost criterion was found to be higher than other criteria in the study. The criterion with the lowest weight was suitable for the fire area. The main reason for this is that there are no alternatives for extinguishers, which would make it difficult to extinguish liquid fires. The dominance of alternatives for each criterion was calculated by applying the steps of TODIM method. The "FOAM EXTINGUISHER", which was the first alternative among the extinguishing devices in terms of fire safety, was determined as the best with the TODIM method.

In addition to extinguishing devices, automatic extinguisher selection was also made in the study, and the foamed automatic extinguishing system was found to be the best. Powder extinguishers, which ranked second among extinguishers, were the worst automatic extinguishers among the alternatives in the automatic powder extinguishing system. The main reason for this is that powder extinguishers harm the environment and they perform poorly in liquid fires compared to other alternatives. And the main reason for its second rank among extinguishing devices is because it has much more suitable cost criteria than other extinguishing devices. The results of the TODIM method also showed a very minimal difference between $\mathrm{A} 2$ and $\mathrm{A} 3$ alternatives.

We can say that this study, which reached its conclusion with the TODIM method, can be applied as it does not require complex application steps and can be easily understood by decision-makers. Moreover, there is no limit to the size of the problem in the methods. In this way, decision-makers can solve the same problem again with criteria, criterion weights, alternatives or other data added to the problem and they can easily update its results. However, increasing the amount of data in the problem also brings the disadvantage of increasing the operations required for the solution and extending the time.

The TODIM method does not take into account the relationships between the criteria discussed. A solution to this may be the use of weighting methods that emphasize the relationship between the criteria when assigning weight to the criteria. The DEMATEL method was applied in this study to determine the criterion weights.

In similar selection problems, another criterion can be selected as the reference criterion instead of the criterion with the highest weight if the TODIM method is used, and differences in the results can be found by changing the value of the loss aversion coefficient. The normalized decision matrix used jointly by both methods can be obtained by other normalization methods and how it changes the results can be observed. Other MCDM methods can also be used to solve the problem and the obtained results can be compared with this study.

The model was created in a structure that can be implemented without the need for special software and allows the judgments of experts to be changed when necessary. By responding quickly to changes in external stakeholders, the selection and ranking process without the need for software is widely adopted by business managers.

\section{Peer-review:}

Externally peer-reviewed

\section{Conflict of interests:}

The author(s) has (have) no conflict of interest to declare.

\section{Grant Support:}

The author(s) declared that this study has received no financial support.

\section{Author Contributions:}

Idea/Concept/Design: M.U. Data Collection and/or Processing: M.U. Analysis and/or Interpretation: M.U., Literature Review: H.Ş., Writing the Article: H.Ş., Critical Review: H.Ş., M.U., Approval: H.Ş., M.U. 


\section{References}

Adali, E. A., Işik, A. T., \& Kundakci, N. (2016). Todim method for the selection of the elective courses. European Scientific Journal, 314-324.

Aksakal, E., \& Dağdeviren, M. (2010). An integrated approach for personel selection with dematel and ANP methods. Journal of the Faculty of Engineering and Architecture of Gazi University, 25(4), 905913

Birgün, S., \& Ulu, M. (2020). Site selection for a training centre focused on industry 4.0 by using dematel and copras. In The International Symposium for Production Research, Springer, Cham, 37-50.

Cinar, Y. (2013). A structural model of career preference problem and attitudes towards risk: a hybrid approach based on stochastic dematel method. Sosyoekonomi, 19(19), 157-186

Costa, A.P.C.S., Almeida, A.T. \& Gomes, L.F.A.M. (2002). Priorities assignment for information systems based on todim multicriteria method. Informing Science, 322-328.

Demirel, F., Tavman, G., \& Yaman M. (2017). Gazi Üniversitesi yeni mimarlık fakülte binasının "binaların yangından korunması hakkında yönetmelik" bağlamında incelenmesi. International Fire and Security Symposium and Exhibition, Istanbul, 313-315.

Efe, B., \& Efe, Ö. F. (2016). An application of value analysis for lean healthcare management in an emergency department. International Journal of Computational Intelligence Systems, 9(4), 689-697.

Efe, Ö. F., \& Efe, B. (2019). Tekstil sektöründe iş kazalarına sebep olan risk faktörlerinin dematel yöntemiyle analizi. Düzce Üniversitesi Bilim ve Teknoloji Dergisi, 7(3), 1162-1175.

Gomes, L. F. A. M. (2009). An application of the todim method to the multicriteria rental evaluation of residential properties. European Journal of Operational Research, 193(1), 204-211.

Gomes, L. F. A. M., Rangel, L. A. D., \& Maranhão, F. J. C. (2009). Multicriteria analysis of natural gas destination in Brazil: an application of the todim method. Mathematical and Computer Modelling, 50(1-2), 92-100.

Gultek, M. (2005). Evaluation of the regulations for shopping centers with atrium in the context of fire safety and simulating the means of egress by the way of sample projects. Unpublished doctoral thesis, Gazi University, Ankara.

Hsu, C. W., Kuo, T. C., Chen, S. H., \& Hu, A. H. (2013). Using dematel to develop a carbon management model of supplier selection in green supply chain management. Journal of Cleaner Production, 56, 164-172.

Iplikçi, E. (2006). Analysis of the fire safety measures in buildings and development of performance criteria related to design of buildings with fire safety. Unpublished master's thesis, Gazi University, Ankara

Kilic, M. (2003). Fire safety and fire extinguisher systems in buildings. Uludag University Journal of The Faculty of Engineering, 8(1), 62-69

Kurt, Z. B., \& Yildiz, A. (2020). Fuzzy topsis based decision model for evaluating and prioritizing r\&d/innovation projects, ar-ge. Electronic Letters on Science and Engineering, 16(2), 93-107.

Li, C. W., \& Tzeng, G. H. (2009). Identification of a threshold value for the dematel method using the maximum mean de-entropy algorithm to find critical services provided by a semiconductor intellectual property mall. Expert Systems with Applications, 36(6), 9891-9898.

Liou, J. J., Yen, L., \& Tzeng, G. H. (2008). Building an effective safety management system for airlines. Journal of Air Transport Management, 14(1), 20-26.

Mahmoodi, M. \& Jahromi, G.S. (2014). A new fuzzy dematel-todim hybrid method for evaluation criteria of knowledge management in supply chain. International Journal of Managing Value and Supply chains (IJMVSC), 5(2), 29-42.

Sen, D. K., Datta, S., \& Mahapatra, S. S. (2015). Extension of todim combined with grey numbers: an integrated decision making module. Grey Systems: Theory and Application, 5(3), 367-391.

Tosun, Ö., \& Akyüz, G. (2015). A fuzzy todim approach for the supplier selection problem. International Journal of Computational Intelligence Systems, 8(2), 317-329. 
Tseng, M.L., Lin, Y.H., Lim, M. K. \& Teehankee, B.L. (2015). Using a hybrid method to evaluate service innovation in the hotel industry. Applied Soft Computing, 28, 411-421

Unal, Z. \& Cetin, E. I. (2020). Selection of crm software in hospitality industry by integrated dematel and todim method. Pamukkale University Journal of Engineering Sciences, 26(4), 779-788.

Wei, C., Ren, Z., \& Rodríguez, R. M. (2015). A hesitant fuzzy linguistic todim method based on a score function. International Journal of Computational Intelligence Systems, 8(4), 701-712.

$\begin{array}{llll}\text { Yangın güvenliği. } & \text { (2019, } & \text { May } & \text { Erişim }\end{array}$ http://www.yangin.org/index.asp?s=makale\&t=teknik_makaleler

Yildiz, A. \& Demir, Y. (2019). Bulanık topsis yöntemiyle Türkiye'nin yerli otomobili için en uygun fabrika yerinin seçimi. BMIJ, 7(4), 1427-1445.

Yildiz, A., \& Yayla, A. Y. (2015). Multi-criteria decision-making methods for supplier selection: a literature review. South African Journal of Industrial Engineering, 26(2), 158-177.

Zhang, X. \& Xu, Z. (2014). The todim analysis approach based on novel measured functions under hesitant fuzzy environment. Knowledge-Based Systems, 61, 48-58. 